\title{
PENGEMBANGAN KURIKULUM BAHASA ARAB PESANTREN MU'ADALAH (Studi Kasus di Pondok Pesantren Al-Kausar Genteng Banyuwangi)
}

\author{
Ro'fat Hizmatul Himmah', Muhammad Afif Amrulloh ${ }^{2}$ \\ ${ }^{1}$ hiezma.amor@gmail.com, ${ }^{2}$ afif.amrulloh@radenintan.ac.id \\ ${ }^{1}$ IAI Darussalam Banyuwangi \\ 2 UIN Raden Intan Lampung
}

\begin{abstract}
Pesantren curriculum as a Mu'adalah between the curriculum at educational institutions using the book and the quality criteria that have been set out in a fair and open. Therefore, this study was conducted to find out an overview of the planning, implementation and evaluation of curriculum development of Arabic at pesantren Al C. This study uses qualitative research methods, descriptive data collection techniques in the form of observation, interview and documentation as well as the use of trainggulasi resources to check the validity of the data. Based on this study, it was found that the Arabic curriculum planning at the boarding school places emphasis on the achievement of language proficiency in the aspects of speaking and reading. This is because diplomas issued synchronised with the Middle East. The book, which provided the material for the study using the book the classic form of Jurumiyah and Imrity for the Nahwu lessons. The direct method of the form sorogan. As for the evaluation of the system using the midle of the semester and semester. Thus, this study is very important to realize service and organization of education boarding schools better through the development of the curriculum based on evaluation and the development needs of the community.
\end{abstract}

Keywords: Kurikulum, pesantren, mu'adalah

\section{PENDAHULUAN}

Pesantren mu'adalah merupakan salah satu arah baru kemajuan model pendidikan yang ada di pondok pesantren. Mu'adalah yang secara harfiah berarti penyetaraan juga merupakan bentuk pengakuan dari pemerintah terhadap keberadaan pondok pesantren secara umum. Bentuk pengakuan pemerintah tersebut adalah memberikan dorongan dari berbagai segi implementasi penyetaraan pondok pesantren tersebut dengan pendidikan formal pada umumnya, seperti pemberian standart isi, pengelolaan bahkan pengakuan akan eksistensi ijazah yang dikeluarkan pondok pesantren tersebut.

Kurikulum pesantren mu'adalah merupakan penyetaraan antara kurikulum pada institusi pendidikan, baik pendidikan di pesantren maupun di luar pesantren dengan menggunakan kriteria baku dan mutu/kualitas yang telah ditetapkan secara adil dan terbuka. Selanjutnya hasil dari mu'adalah tersebut dapat dijadikan dasar dalam meningkatkan pelayanan dan penyelenggaraan pendidikan di pondok pesantren. 
Dalam konteks ini, buku pedoman pesantren mu'adalah yang diterbitkan oleh Kementrian Agama pada tahun 2009 diungkapkan bahwa:

"Pondok pesantren mu'adalah yang terdapat di Indonesia terbagi menjadi 2 (dua) bagian; Pertama, pondok pesantren yang lembaga pendidikannya dimu'adalahkan dengan lembaga-lembaga pendidikan di luar negeri seperti Universitas al-Azhar Kairo Mesir, Universitas Umm al-Qurra Arab Saudi maupun dengan lembaga-lembaga non formal keagamaan lainnya yang ada di Timur Tengah, India, Yaman, Pakistan atau di Iran. Pondok pesantren-pondok pesantren yang $m u$ 'adalah dengan luar negeri tersebut hingga saat ini belum terdata dengan baik karena pada umumnya mereka langsung berhubungan dengan lembaga-lembaga pendidikan luar negeri tanpa ada koordinasi dengan Depag RI maupun Departemen Pendidikan Nasional. Kedua, pondok pesantren mu'adalah yang disetarakan dengan Madrasah Aliyah dalam pengelolaan Depag RI dan yang disetarakan dengan SMA dalam pengelolaan Diknas. Keduanya mendapatkan SK dari Dirjen terkait."1

Berdasarkan hal itu, dapat dipahami bahwa jenis pesantren mu'adalah di Indonesia ada dua jenis, yaitu pesantren mu'adalah yang disetarakan ijazahnya setara dengan SMA

\footnotetext{
${ }^{1}$ Choirul Fuad Yusuf, Pedoman Pesantren Mua'adalah, (Jakarta: Direktur jendral Direktur Pendidikan Diniyah dan Pondok Pesantren, 2009), hlm. 8
}

Al-Azhar dan bisa melanjutkan studi pendidikan ke Universitas Al-Azhar Mesir dan Universitas Umm al-Quro Arab Saudi. Sedangkan jenis yang kedua yaitu, pesantren mu'adalah yang ijazahnya di setarakan dengan pengelolaan Madrasah Aliyah di bawah pengelolaan Departemen Agama ataupun pesantren mu'adalah yang disetarakan dengan SMA yang pengelolaannya di bawah Departemen Pendidikan Nasional.

Seperti penelitian yang dilakukan oleh Ismail Suardi Wekke yang berjudul "Tradisi Pesantren dalam Konstruksi Kurikulum bahasa Arab di Lembaga Pendidikan Minoritas Muslim Papua Barat" menyatakan bahwa pesantren sebagai pilar tradisi yang mampu memberikan kontribusi terhadap masyarakat. Oleh karean itu, salah satu instruksional yang utama untuk melaksanakan pengajaran dan pembelajaran yaitu dengan menggunakan kurikulum. $^{2}$

Dalam penelitiannya yang lain, Ismail Suardi Wekke juga melakukan kajian terhadap penembangan kurikulum yang berjudul "Pesantren dan Pengembangan Kurikulum Kewirausahaan, Kajuan Pesantren

\footnotetext{
${ }^{2}$ Ismail Suardi Wekke.2014.Tradisi Pesantren dalam Konstruksi Kurikulum bahasa Arab di Lembaga Pendidikan Minoritas Muslim Papua Barat.Jurnal KARSA, Vol.22 No.1
} 
Roudhatul Khuffadz Sorong Papua Barat". Penelitian tersebut mengkaji tentang pengembangan kurikulum yang dilakukan oleh pesantren Roudhatul Khuffadz yaitu dengan beberapa kajian dan diskusi. ${ }^{3}$

Dari beberapa kajian pustaka, belum banyak ditemukan kajian tentang pengembangan bahasa Arab di pesantren mu'adalah berkaitan dengan pengembangan kurikulum, penulis hanya menemukan kajian-kajian pada manajemen kurikulum serta implementasinya. Perbedaan dari kajian sebelumnya kurikulum bahasa Arab di pesantren itu membahas tentang manajemen dan penyetaraan ijazah formal sedangkan penelitian ini membahas tentang penyetaraan ijazah yang bekerja sama dengan Timur Tengah.

\section{LANDASAN TEORI}

Pengembangan Kurikulum Bahasa Arab. Kurikulum bahasa Arab pada dasarnya merupakan suatu fungsi hubungan yang terjalin antara keprihatinan pengajar dan faktor-faktor lainnya yang terlibat dalam sistem-sistem nilai pendidikan, teori dan praktek dalam

\footnotetext{
${ }^{3}$ Ismail Suardi Wekke.2012.Pesantren dan Pengembangan Kurikulum Kewirausahaan; Kajian Pesantren Roudahtul Khuffadz Sorong Papua Barat.Jurnal INFERENSI, Jurnal Penelitian Sosial Keagamaan.Vol.6,No.2 Desember 2012
}

rancang bangun kurikulum, kearifan pengalaman para pengajar dan motivasi para pembelajar. Untuk memahami kurikulum bahasa Arab dalam setiap konteks tertentu, maka kita perlu berupaya memahami bagaimana semua pengaruh yang beraneka ragam itu saling berkaitan untuk memberikan suatu bentuk tertentu bagi perencanaan dan pelaksanaan proses pembelajaran.

Sebagaimana pengembangan kurikulum yang lain, pengembangan kurikulum bahasa Arab terdiri dari tiga aspek, yaitu perencanaan, pelaksanaan dan evaluasi, berikut adalah uraian mengenai ketiga aspek pengembangan bahasa Arab tersebut.

\section{a. Perencanaan kurikulum bahasa}

\section{Arab}

Setiap kegiatan pasti melalui proses perencanaan, termasuk di dalamnya pengembangan kurikulum bahasa Arab. Perencanaan merupakan suatu rangkaian proses kegiatan menyiapkan keputusan mengenai apa yang diharapkan terjadi (peristiwa, keadaan, suasana, dan sebagainya) dan apa yang akan dilakukan (revisi,inovasi, dan lain sebagainya). ${ }^{4}$

\footnotetext{
${ }^{4}$ Udin Syaefudin Sa'id dan Abid
} Syamsudin Makmun, Perencanaan Pendidikan : Suatu pendekatan Komperhersif, (Bandung : PT Rosdakarya, 2007), hlm 3 
Merancang sebuah kurikulum bahasa memerlukan adanya pertimbangan terhadap beberapa hal, mulai dari tujuan linguistik dan materinya sampai pada spesifikasi kegiatan pengajaran dengan teknik evaluasi. ${ }^{5}$

\section{b. Pelaksanaan Kurikulum Bahasa Arab}

Pelaksanaan kurikulum bahasa Arab merupakan pelaksanaan progam yang telah dikembangkan dalam tahap sebelumnya, yaitu perencanaan. Pelaksanan kurikulum bahasa Arab menempatkan pengembangan kretivitas siswa lebih dari penguasaan materi. Dalam kaitannya ini, siswa di tempatkan sebagai subyek dalam proses pembelajaran. ${ }^{6}$

Menurut Henri Guntur Tarigan, Implementasi kurikulum bahasa Asing meliputi dua hal: 1) implementasi progam. Sebagai pemeran pengambilan keputusannya adalah penulis bahan dan latihan untuk mengajar yang menghasilkan produk berupa materi dan pelatihan pengajar. 2) implementasi kelas, yang diperankan oleh pengajar dan pembelajar dan menghasilkan prodal

${ }^{5}$ Syukur Ghazali, Pembelajaran Ketrampilan Berbahasa: dengan Pendekatan Komunikatif-Interaktif (Bandung: PT Rafika Aditama, 2010), hlm 75

${ }^{6}$ Rusman, Manajemen....,hlm 75 berupa kegiatan pengajar dan pembelajar. $^{7}$

\section{c. Evaluasi Kurikulum Bahasa Arab}

Dalam pengembangan kurikulum, evaluasi merupakan salah satu komponen penting dan tahap yang harus ditempuh untuk mengetahui efektifitas kurikulum. Hasil yang diperoleh dapat dijadikan balikan (feed-back)dalam memperbaiki dan menyempurnakan kurikulum. Evaluasi kurikulum merupakan usaha yang sulit dan kompleks, karena banyak aspek yang harus dievaluasikan, banyak orang yang terlibat, dan luasnya kurikulum yang diperhatikan. ${ }^{8}$

Evaluasi kurikulum secara mendasar dapat dilakukan pada komponen-komponen kurikulum. Hal ini dapat dipahami dari pendapat S. Nasution yang mengemukakan bahwa jika seorang evalator mau melakukan evaluasi kurikulum maka harus mengevaluasi komponen-komponen kurikulum yang meliputi : 1) tujuan kurikulum, 2) pengalaman-pengalaman belajar untuk mengembangkan pengetahuan sikap, dan ketrampilan murid, 3) organisasi pengalaman itu, hubungannya dengan

${ }^{7}$ Henri Guntur Tarigan, Dasar-dasar Kurikulum Bahasa (Bandung : Angkasa, 2009), hlm 27

93 
pengalaman lain, 4) cara-cara mengevaluasi hasil belajar murid. ${ }^{9}$

Dari beberapa pengertian menunjukan bahwa yang dimaksud dengan evaluasi kurikulum bahasa Arab adalah kegiatan yang teratur dan berkelanjutan berdasarkan kelebihan dan kekurangan dari fakta di lapangan yang berupa prestasi belajar peserta didik. Tujuannya adalah untuk mengetahui (1) sejauh mana para pelaku di lapangan sudah memahami dan menguasai kurikulum lengkap dengan komponennya, (2) sejauh mana efektifitas pelaksanaan kurikulum, (3) sejauh mana efektifitas penggunaan sarana dan prasarana, (4) sejauh mana peserta didik telah mencapai tujuan atau menguasai pengetahuan ketrampilan, dan sikap yang diharapkan, (5) adakah dampak pelaksanaan kurikulum baik positif atau negatif. ${ }^{1}$

\section{METODE PENELITIAN}

Penelitian ini merupakan jenis penelitian lapangan (field research) dan masuk pada kategori penelitian kualitatif. Dari aspek pembahasannya, penelitian ini merupakan penelitian deskriptif kualitatif yaitu suatu penelitian yang hanya

${ }^{9}$ S. Nasution, Asas-asas Kurikulum (Jakarta: Bumi Aksara, 2006), hlm 253

1 Oemar Hamalik, Dasar-dasar Pengembangan Kurikulum (Bandung: PT Remaja Rosdakarya, 2007), hlm 237 melukiskan, memaparkan dan melaporkan suatu keadaan, suatu obyek atau peristiwa dengan menarik suatu kesimpulan. ${ }^{1}$

Adapun sumber data dalam penelitian ini adalah sumber data utama dan sumber data tambahan yang berupa dokumen-dokumen. Sumber data utama (primer) meliputi: pengasuh pondok pesantren Al-Kautsar dan Baitul Arqom, koordinator kurikulum mu'adalah, dan guru mu'adalah. Sumber data tambahan (sekunder) seperti: kurikulum pesantren mu'adalah pondok pesantren Al-Kautsar dan Baitul Arqom, dokumentasi kurikulum pesantren mu'adalah pondok pesantren Al-Kautsar dan Baitul Arqom, sejarah adanya kurikulum pesantren mu'adalah pondok pesantren Al-Kautsar dan Baitul Arqom.

Adapun teknik pengumpulan data yang perlukan dalam penelitian ini, penulis menggunakan observasi, wawancara, dan dokumentasi. Teknik analaisis data mencakup: ${ }^{1}$ reduksi data, display data, dan penarikan kesimpulan/verifikasi.

\section{HASIL DAN PEMBAHASAN}

\footnotetext{
1 Kartini Kartono, Pengantar Metodelogi Riset Sosial (Bandung: mandar Maju, 1999) hlm, 29

1 Moh. Nasir, Metode Penelitian(Jakarta: Ghalia Indonesia, 2003), hlm. 23
} 
Pengembangan Kurikulum Bahasa Arab di Pondok Pesantren Al-Kautsar Banyuwangi

Sejarah pengembangan kurikulum bahasa Arab Pondok Pesantren AlKautsar pada awalnya berbentuk pesantren salafiyah kemudian pada tahun 1996 pesantren

Al-Kautsar mengembangkan pesantren modern, perubahan tersebut dikarenakan faktor internal tujuannya agar menjadi ciri khas dari pondok pesantern tersebut, sebagaimana mengacu pada Pesantren Modern Gontor, namun tidak meninggalkan nuansa salafiyahnya.

Dalam kerangaka teoritis ada lima prinsip dalam pengembangan kurikulum, yaitu prinsip relevansi, prinsip fleksibilitas, prinsip kontinuitas, prinsip efisiensi, dan prinsip efektivitas. Salah satu pengembangan kurikulum adalah adanya perumusan rasional yang tertuang dalam target dan tujuan. Rumusan rasional itu tertuang pada bentuk pertimbangan pencapaian target yaitu sebagaimana yang terdapat pada penyajian data pesantren Al-Kautsar diantaranya adalah : pertama merealisasikan target dari visi dan misi yang terdapat dalam pesantren Al-Kautsar yaitu menjadikan out-put santri yang "muttafaqqih fiddin", kedua adanya jalinan kerjasama dengan luar negeri, khususnya Yaman, Singapura, dan Malaysia.

Dalam berbagai kesempatan wawancara dapat dipahami bahwa pengembangan kurikulum bahasa Arab diperlukan proses perencanaan, kurikulum sebagai upaya untuk memahami apakah sudah sesuai antara kurikulum yang diterapkan dengan yang sudah direncanakan. Berikut dikemukakan rangkaian perencanaan, pengembangan kurikulum bahasa Arab dimaksud di Pesantren Al-Kautsar Banyuwangi.

\section{Perencanaan}

Pengembangan

\section{Kurikulum Bahasa Arab}

Berdasarkan hasil wawancara, observasi dan dokumentasi, perencanaan kurikulum bahasa Arab di Pesantren AlKautsar berawal dari penetapan target pembelajaran bahasa Arab, jadwal pelajaran, metode dan sistem evaluasi.

Dalam proses perencanaan kurikulum, pesantren Al-Kautsar mengembangkan pedoman penetapan bahan untuk kurikulum pendidikan yang meliputi :

a. Penetapan Tujuan

Target atau tujuan pembelajran bahasa Arab yang pesantren Al-Kautsar canangkan ada empat yaitu kemampuan bahasa dalam hal qiro'ah, muhadatsah, istima', dan kemampuan 
kitabah. Dari keempat kemampuan pesantren hanya menekankan pada dua kemampuan diantaranya pertama, kemampuan membaca yang berorentasi pada fahmul kutub, kedua, kemampuan muhadatsah untuk membekali para santri melanjutkan ke Negara Yaman dan speaking membekali ke Singapura dan Malaysia. ${ }^{1}$

Setelah tujuan bahasa Arab dirumuskan, kemudian melakukan progam untuk mendukung ketercapaian tujuan pembelajaran bahasa Arab mulai dari jadwal pelajaran yang berpihak pada tujuan pembelajaran bahasa Arab, progam pendukung sampai pada bentuk evaluasi. Tujuan pembelajaran bahasa Arab di pesantren Al-Kautsar ada empat target yaitu:

1. Untuk kemampuan membaca didukung dengan pembalajaran nahwu shorof yang intensif, didukung juga dengan kegiatan diniyah yang pelajarannya memakai kitab kuning klasik.

2. Untuk kemampuan berbicara diadakannya lingkungan bahasa, yang setiap paginya santri muhadatsah di halaman, santri dilatih terus untuk berbicara

1 Hasil wawancara dengan KH. Nur Hamid Iskandar, pada tanggal 16 Februari 2014 bahasa untuk mecapai target kemampuan berbicara.

3. Untuk kemampuan menulis santri diajarkan pelajaran imla' dan insya'.

4. Untuk kemampuan mendengar pesantren menyediakan laboratorium bahasa serta lingkungan bahasa. ${ }^{1}$

Penetapan keempat tujuan pembelajaran bahasa Arab di Pesantren Al-Kautsar memiliki pertimbangan aspek empiris dan filosofis, sebagaimana yang tertuang dalam kajian teori. Pertimbangan itu diambil karena sebuah tuntutan dari visi dan misi yang ada di pesantren AlKautsar yaitu menciptakan santri yang mutafaqqih fiddin. Pada aspek filosofis dapat diterjemahkan bahwa penetapan tujuan pembelajaran tersbut sebagai jawaban atas keberhasilan santri dalam melanjutkan belajar ke Negara Yaman. Rumusan perencanaan tujuan kurikulum Bahasa Arab ditetapkan pada tujuan dalam bentuk kegiatan formal maupun non formal.

b. Identifikasi Materi

Untuk merealisasikan target, pesantren mendesain materi dengan dua kategori yaitu kategori materi inti dan

1 Hasil wawancara dengan KH. Nur Hamid Iskandar, pada tanggal 16 Februari 2014 
materi penunjang. Disamping itu juga mempunyai kegiatan lain yang menunjang ke arah pencapaian target. Untuk materi inti bahasa Arab menggunakan kitab almuhawarah, kitab ini adalah kitab yang melatih santri untuk berbicara bahasa Arab, sementara pada pencapaian kemahiran membaca bahasa Arab ada pada pelajaran di waktu sekolah diniyyah. Untuk materi penunjang yaitu nahwu, muthola'ah, mahfudzot dan insya'. Dan kegiatan penunjang yaitu lomba debat bahasa serta penciptaan lingkungan bahasa. $^{1}$

Berdasarkan hasil wawancara dengan ustadz Ali Mansur dapat dipahami bahwa perencanaan kurikulum bahasa Arab di Pondok Pesantren Al-Kautsar dimulai dari penyusunan jadwal pelajaran serta merumuskan jumlah jam dalam pertemuan, penentuan ustadz. Dalam konteks jadwal pelajaran pihak pesantren mencoba menyusun secara integral mengenai kurikulum bahasa Arab artinya merumuskan jadwal beserta jumlah jam pertemuan mulai dari kelas I sampai kelas VI berdasarkan tingkat kebutuhan. Dalam data dokumentasi dapat diketahui bahwa struktur kurikulum sudah memiliki komponen tersendiri dalam materi bahasa Arab yaitu Al-Imla', Al-Insya', Al-

1 Hasil wawancara dengan Usế. Ali Manshur, S.Fil.I, Kepala Pondok Pesantren al-Kautsar, pada
Muthola'ah, An-Nahwu, Ash-Shorof, AlBalaghoh, At-Tarjamah, Mahfudzot, disamping itu juga ada materi dalam kitab muhawarah yang semuanya menggunakan bahasa Arab dan dalam kelas formal juga terdapat pelajaran bahasa Arab dari

Kementerian Agama (Departemen Agama). Khusus untuk materi bahasa Arab jumlah jam dalam satu tahun untuk semua kelas berjumlah 159 jam bila dibandingkan dengan materi-materi lain. ${ }^{1}$

6

Materi bahasa Arab di kelas formal juga mengikuti kurikulum Nasional, jadi terdapat buku LKS untuk latihan para santri dan buku paket bahasa Arab dari Depag. Selain itu, juga terdapat materi penunjang dalam pelajaran diniyah atau di pesantren itu sendiri.

Kurikulum Madrasah Aliyah Pondok Pesantren Al-Kautsar sama dengan kurikulum sekolah menengah atas, hanya saja di Madrasah Aliyah AlKautsar terdapat porsi lebih banyak muatan pendidikan agama Islam yaitu Fiqih, Aqidah Akhlak, al-Qur'an Hadits, Bahasa Arab dan Sejarah Islam, sedangkan kurikulum khusus pondok pesantren Nahwu, Shorof, Tahfizul 
Qur'an, faroid, Balaghoh, Insya', Falak, Tafsir Qur'an, Al-Hadits, Kajian Kitab Kuning.

Dalam pengembangan kurikulum bahasa Arab di Pesantren Al-Kautsar menggunakan landasan-landasan dan prinsip-prinsip pengembangan kurikulum berikut ini :

a) Landasan Pengembangan Kurikulum Pesantren Al-Kautsar

Sebagai sebuah inti dari pendidikan, kurikulum memiliki pengaruh terhadap seluruh aktifitas pendidikan. Mengingat pentingnya kurikulum, maka penyusunan kurikulum tidak dapat dilakukan secara sembarangan.

Penyusunan pengembangan kurikulum membutuhkan landasan yang kuat, yang didasarkan dari hasil-hasil pemikiran dan penelitian mendalam. Penyusunan kurikulum yang tidak didasarkan pada landasan yang kuat dapat berakibat fatal terhadap kegagalan pendidikan itu sendiri.

Pendidikan di pondok pesantren mu'adalah mengikuti standard DEPAG maupun DIKNAS, dan senantiasa berusaha untuk mengembangkan diri, memiliki beberapa landasan pengembangan kurikulum yang didasari sesuai dengan visi, misi, serta tujuan

1 Hasil waancara dengan Usaté Ali Mansur, S.Fil.I tanggal 18 Februari 2014 pesantren itu sendiri. Berikut ini rinciannya sebagai berikut :

1) Landasan Filosofis

Landasan Filosofis akan memberikan susunan kurikulum yang mengandung suatu kebenaran terutama kebenaran di bidang nilai-nilai sebagai pandangan hidup yang diyakini dari suatu kebenaran. Hal tersebut karena suatu kajian filsafat adalah system nilai yang berkaitan dengan cara hidup dan kehidupan, norma-norma yang muncul dari individu sekelompok masyarakat ataupun bangsa yang dilatarbelakangi oleh pengaruh agama, adat istiadat dan konsep individu tentang pendidikan.

Di Pondok pesantren Al-Kautsar pola pendidikan yang digunakan adalah full day school, santri sekolah di AlKautsar wajib berada di asrama. Sehingga selama dua puluh empat jam, Kiai beserta para guru senantiasa membimbing, mengajar dan mendidik santri-santrinya, baik dengan keteladanan dengan cara hidup. ${ }^{1}$

Selain itu mata pelajaran yang diajarkan yang diharapkan bisa membentuk kepribadian yang baik dan bijaksana dalam tingkah lakunya

\footnotetext{
1 Hasil wawancara dengan KH. Nur Hamid, Pengasuh Pesantren Al-Kautsar, pada tanggal 16 Februari 2014
} 
adalah pendidikan akhlaq dengan kitab bidayatul hidayah.

2) Landasan Psikologi.

Dasar Psikologi terbagi kepada dua macam yaitu pertama, psikologi pelajar dan hakikat anak dapat dididik, diajarkan dan diberikan sejumlah materi dan pengetahuan. Kedua, psikologi anak. Setiap anak mempunyai kepentingan yakni untuk mendapatkan situasi-situasi belajar kepada anak untuk mengembangkan bakatnya.

Di pondok pesantren Al-Kautsar menggunakan sistem asrama, jadi kebersamaan antara Kiai, guru dan santri dapat berlangsung terus menerus dan hubungan mereka menjadi semakin luas. Dengan keleluasaan ini dan frekuensi kontak yang lebih intens, segala persoalan segera akan mendapatkan perhatian dan pemecahannya. Perjumpaan Kyai, guru dan santri tidak hanya dibatasi oleh jam-jam belajar di kelas. Kondisi ini sangat baik bagi proses pembentukan kepribadian santri. Apabila kondisi seperti ini dipergunakan secara efektif, maka semakin besar peluang untuk dapat mencapai tujuan akhir pendidikan.

3) Landasan Sosial Budaya.
Landasan sosial budaya adalah pentingnya aspek-aspek sosial dan budaya yang berkembang di masyarakat yang dijadikan acuan pengembangan kurikulum. Hal ini berangkat dari satu premis bahwa pendidikan lahir dari, oleh, dan untuk masyarakat dan budaya. Di sini ada hubungan timbal balik yang harmonis antara pendidikan, masyarakat dan budaya.

Pondok pesantren Al-Kautsar tetap konsisten pada peranannya sebagai sebuah yayasan pendidikan yang memberikan pelayanan sosial pada masyarakat sekitar. Oleh karena itu setiap lulusan pesantren Al-Kautsar wajib melaksanakan pengabdian selama tiga bulan untuk terjun kepada masyarakat sekitar, setelah itu wajib melaksanakan pengabdian mengajar kepada pesantren al-Kautsar. ${ }^{1}$

b) Prinsip-prinsip pengembangan kurikulum bahasa Arab Pesantren AlKautsar.

Prinsip-prinsip yang akan digunakan dalam kegiatan kurikulum bahasa Arab pada dasarnya merupakan kaidah-kaidah atau hukum yang akan menjiwai suatu kurikulum. 
Pondok Pesantren Al-Kautsar dalam pengembangan kurikulum bahasa Arab menggunakan prinsip-prinsip sebagai berikut :

1) Prinsip berorientasi pada tujuan; dimaksudkan agar perumusan kurikulum lainnya serta semua kegiatan pembelajaran didasarkan dan mengacu pada tujuan yang akan dicapai. Adapun tujuan kurikulum bahasa Arab di Pondok Pesantren Al-Kautsar adalah pada empat pencapaian kemahiran.

2) Prinsip relevansi; secara internal bahwa kurikulum memiliki relevansi diantara komponenkomponen kurikulum (tujuan, bahan, strategi, organisasi, dan evaluasi). Sedangkan secara eksternal bahwa komponenkomponen tersebut memiliki relevansi dengan tuntutan ilmu pengetahuan dan teknologi (relevansi epistomologis), tuntutan dan potensi peserta didik (relevansi psikologis) serta tuntutan dan kebutuhan perkembangan masyarakat (relevansi sosiologis). Oleh karena itu, pesantren menyusun kurikulum sesuai dengan perkembangan zaman.

1 Hasil wawancara dengan KH. Nur Hamid, Pengasuh Pesantren Al-Kautsar, pada tanggal 16
3) Prinsip efektifitas; yakni mengusahakan agar kegiatan pengembangan kurikulum mencapai tujuan. Pondok Pesantren Al-Kautsar menerapkan sistem pendidikan yang memberikan pengajaran dua puluh empat jam dengan agenda yang padat.

4) Prinsip efisiensi; yakni mengusahakan agar dalam pengembangan kurikulum dapat mendayagunakan waktu, biaya dan sumber-sumber lain yang ada secara optimal, cermat dan tepat, sehingga hasilnya memadai. Tenaga pengajar di Pondok Pesantren Al-Kautsar kebanyakan adalah alumni dari pesantren sendiri. Sehingga pendaftaran guru dari luar pesantren bisa dibatasi.

5) Prinsip kontinuitas; yakni adanya kesinambungan dalam kurikulum baik secara vertikal maupun secara horizontal. Pondok Pesantren AlKautsar mengorganisasikan mata pelajaran disusun secara berkesinambungan dan sesuai dengan silabus dan setiap guru wajib membuat RPP. Serta terdapat kelas khusus bagi santri untuk mengantisipasi hetrogen lulusan santri, terdapat matrukulasi 3 bulan 
untuk mendalami bahasa Arab dan Inggris.

6) Prinsip sinkronisasi; dimaksudkan adanya sifat yang searah dan tujuan dengan semua kegiatan yang dilakukan oleh kurikulum. Mata pelajaran formal dan non formal di Pondok Pesantren Al-Kautsar saling berkaitan atau dapat dikatakan bahwa kitab yang dikaji dalam pendidikan non formal dimaksudkan untuk menunjang pendidikan non formal seperti halnya kitab imrithi dalam pengajian diniyyah akan menunjang pelajaran nahwu dalam formalnya. Dalam kegiatan muhadatsah santri diberi sanksi agar tertib menjalankan muhadtsah di lingkungan pesantren, di sekolah maupun di kantin santri wajib menggunakan bahasa Asing. ${ }^{1}$

c) Pemilihan Metode

Metode pembelajaran yang digunakan oleh pesantren Al-Kautsar tergolong unik, dimana pesantren modern tapi masih menyelipkan nuansa salafiyahnya dengan menggunakan metode sorogan. Metode sorogan di sini metode yang guru membaca kitab kuning dan santri memaknainya dengan bahasa
Jawa padahal santri diwajibkan sehari-harinya menggunakan bahasa Asing. Menurut peneliti ini merupakan salah satu kekurangan dalam pembiasaan santri dalam berbahasa, memang ada kelebihan tersendiri santri bisa mengetahui ilmu alat dengan metode sorogan itu sendiri. Kemudian metode langsung, metode ini dalam pembelajaran juga sering digunakan oleh para guru bahasa Arab. Guru di Pesantren AlKautsar menggunakan metode langsung guna agar interaksi langsung dengan para santri dan santri juga bisa aktif dalam pembelajaran.

d) Evaluasi Pembelajaran

Sistem ${ }^{9}$ Evaluasi di Pondok Pesantren Al-Kautsar menggunakan ujian lisan dan tulis. Ujian lisan berguna untuk menunjang kemampuan berbahasa santri. Bagi kelas 6 ada ujian praktek mengajar dengan menggunakan bahasa arab dan bahasa inggris sebagai bekal untuk melatih mental sebagai seorang pengajar. Ketika santri tidak lulus evaluasi, akan ada ujian susulan atau remidi. Kemudian bagi 
kelas 6 setingkat kelas 3 MA, dinyatakan lulus dengan adanya pengabdian selama satu tahun, guna melihat bagaimana bukti pengabdian santri untuk pesantren.

Evaluasi pembelajaran di pesantren Al-Kautsar ini mencakup tiga ranah yaitu penilaian kognitif, psikomotorik, dan afektif. Penilaian kognigtif pada tes midle semester dan semeter sedangkan penilaian afektif pada keaktifan siswa ketika berada di pesantren sedangkan penilaian psikomotorik dilihat dari pengabdian santri.

Untuk santri yang berminat untuk melanjutkan ke timur tengah diadakan kelas khusus, santri di gembleng dalam berbicara bahasa Arab.

Data santri yang melanjutkan ke Timur Tengah ${ }^{2}$ :

\begin{tabular}{|l|l|l|l|}
\hline No & Tahun & $\begin{array}{l}\text { Jumlah } \\
\text { santri }\end{array}$ & Universitas \\
\hline 1 & 2006 & 3 & $\begin{array}{l}\text { Al-Azhar } \\
\text { Cairo }\end{array}$ \\
\hline 2 & 2008 & 4 & $\begin{array}{l}\text { Al-Ahqof } \\
\text { Yaman dan } \\
\text { Kharoum }\end{array}$ \\
\hline
\end{tabular}

Februari 2014

2 Hasil wawancara dengan KH. Nur Hamid Iskandar, pada tanggal 16 Februari 2014

\begin{tabular}{|l|l|l|l|}
\hline & & & Sudan \\
\hline 3 & 2010 & 1 & $\begin{array}{l}\text { Al-Ahqof } \\
\text { yaman }\end{array}$ \\
\hline 4 & 2011 & 2 & $\begin{array}{l}\text { Al-Azhar } \\
\text { Cairo }\end{array}$ \\
\hline 5 & 2012 & 1 & $\begin{array}{l}\text { Al-Ahqof } \\
\text { Yaman }\end{array}$ \\
\hline
\end{tabular}

Sistem pendidikan di Pondok Pesantren Modern Al-Kautsar adalah mengikuti kurikulum Departemen Pendidikan Agama dan kurikulum Departemen Pendidikan dan Kebudayaan serta kurikulum khusus Pondok Pesantren Modern dengan bahasa pengantar bahasa Arab atau bahasa Inggris yang mengacu kepada terciptanya alumni (out put) yang menguasai bahasa Arab dan bahasa Inggris, baik aktif maupun pasif dan o mempunyai kemauan dan kemampuan untuk mengajar (amaliyah al-tadris) dengan bahasa Arab atau Inggris pada anak didik tingkat dasar.

Di samping itu, juga di tambah dengan pendidikan ketrampilan seperti komputer, laboratorium bahasa, kepramukaan, jam'iyatul qura', praktek ubudiyah praktis dan khitobah dengan menggunakan tiga bahasa (pidato bahasa Arab, Inggris dan Indonesia), cabangcabang olahraga, kesenian kaligrafi, letter 
dan kegiatan-kegiatan ketrampilan lainnya. $^{2}$

Perencanaan kurikulum bahasa Arab di Pondok Pesantren Al-Kautsar adalah dimulai dari penetepan tujuan pembelajaran bahasa Arab, menyusun matrei beserta jumlah jam, penetapan metode pembelajaran, serta evaluasi pembelajaran dilakukan 4 kali dalam setahun midle semester, semester ganjil dan genap. Pelaksanaan kurikulum bahasa Arab di Pondok Pesantren Al-Kautsar adalah penyusunan progam-progam dari progam harian, mingguan, bulanan serta tahunan, pelaksanaan kelas pada Pesantren Al-Kautsar terdapat kelas formal yang kurikulumnya mengikuti Departemen Pendidikan Agama dan kurikulum Departemen Pendidikan dan Kebudayaan dan selanjutnya kelas diniyah mengembangkan kurikulum khusus pesantren.

Namun demikian, jika dilihat dari pengembangan kurikulum yang seharusnya dilakukan secara berkelanjutan, maka praktek perencanaan yang duilakukan di Pondok Pesantren AlKautsar dirasa sangat kurang memadai, maka dari itu perlu pengembangan kurikulum yang harus

2 Hasil wawancara dengan Ustadzah Ayu Surga Wiyasari, L.c pada tanggal 13 Februari 2014 mempertimbangkan perkembangan zaman dan tuntutan masyarakat. Semisal tuntutan zaman sekarang yang mengedepankan pentingnya skill selain pendalaman ilmu keislaman di Pondok Pesantren, sehingga lulusan pesantren bisa diandalkan kemampuan agama dan bahasa Arab, selain itu memiliki skill untuk kesiapan hidup di tengah-tengah masyarakat yang selalu berkembang dinamis. Seperti halnya kedinamisan bahasa Arab yang selalu terus berkembang mengikuti perkembangan zaman. $^{2}$

\section{SIMPULAN DAN SARAN}

Dari hasil kajian ini dapat ditarik kesimpulan bahwa dalam pengembangan kurikulum, salah langkah awal yang dilakukan adalah perencanaan kurikulum. Perencanaan ini dilakukan agar kurikulum dapat terlaksana dengan baik dan sesuai dengan harapan. Perencanaan pengembangan kurikulum bahasa Arab pada pesantren tersebut dimulai dari penetapan tujuan pembelajaran bahasa Arab, identifikasi materi, pemilihan metode serta evaluasi pembelajaran. Sehingga dengan demikian diharapkan pondok pesantren mampu menjadi pusat pembentukkan santri yang berdaya buga

2 Muhammad Afif Amrulloh.2016. تغيير فونيمات اللغة في Jurnal Al Bayan; Jurnal العربية المستعرة في اللغة الجاوية. Jurusan Pendidikan Bahasa Arab.Vol.8,No.2 Desember 2016 
bagi masyarakat sekitar melalui pengembangan kurikulum yang baik. Oleh karena itu, masih diperlukan penelitian berikutnya yang lebih mendalam terkait pengembangan kurikulum untuk terwujudnya penyelenggaraan pendidikan di pondok pesantren yang lebih baik.

DAFTAR PUSTAKA

Amrulloh, Muhammad Afif.2016. تغيير فونيمات اللغة العربية المستعرة في اللغة Jurnal Al Bayan; Jurnal Jurusan Pendidikan Bahasa Arab.Vol.8,No.2 Desember 2016

Ghazali, Syukur, Pembelajaran Ketrampilan Berbahasa; dengan Pendekatan KomunikatifInteraktif, Bandung, PT. Rafika Aditama, 2010.

Hamalik, Oemar, Pengembangan Kurikulum, Bandung: Bandar Maju, 1999.

Kartono, Kartini, Pengantar Metodelogi Riset Sosial, Bandung: Bandar Maju, 1999.

Nasir, Moh, Metode Penelitian, Jakarta: Ghalia Indonesia, 2003.

S. Nasution, Asas-asas Kurikulum, Jakarta: Bumi Aksara, 2006.

Sa'id, Udin Syaefullah dan Abin Syamsuddin, Perencanaan Pendidikan: Suatu Pendekatan Komprehensif, Bandung: PT Remaja Rosdakarya, 2007.

Tarigan, Henry Guntur, Dasar-dasar kurikulum Bahasa, Bandung: Angkasa, 2009.

Yusuf, Choirul Fuad, Pedoman Pesantren Mua'adalah, Jakarta: Direktur jendral Direktur Pendidikan Diniyah dan Pondok Pesantren, 2009.

Wekke, Ismail Suardi.2012.Pesantren dan
Pengembangan Kurikulum

Kewirausahaan; Kajian Pesantren Roudahtul Khuffadz Sorong Papua Barat.Jurnal INFERENSI, Jurnal Penelitian Sosial Keagamaan.Vol.6,No.2 Desember 2012

.2014.Tradisi Pesantren dalam Konstruksi Kurikulum bahasa Arab di Lembaga Pendidikan Minoritas Muslim Papua Barat.Jurnal KARSA, Vol.22,No.1. Juni 2014 